\title{
EFFECT OF 2\% IODINE DISINFECTING SOLUTION ON BOND STRENGTH TO DENTIN
}

\author{
EFEITO DA SOLUÇÃO DESINFETANTE DE IODO A 2\% SOBRE A ADESÃO À DENTINA
}

\author{
Nelson Renato Franca Alves da SILVA', Christine S. CALAMIA², Paulo G. COELHO ${ }^{3}$, Marcela Rocha de Oliveira CARRILHO ${ }^{4}$, \\ Ricardo Marins de CARVALHO ${ }^{5}$, Page CAUFIELD ${ }^{6}$, Van P. THOMPSON ${ }^{7}$
}

\author{
1- DDS, MS, PhD, Assistant Professor, Department of Biomaterials and Biomimetics, Department of Prosthodontics, New York University \\ College of Dentistry, NY, USA. \\ 2- Graduate Student at New York University College of Dentistry, NY, USA. \\ 3- BS. Biomaterials and Biomimetics. New York University College of Dentistry, USA. \\ 4- DDS, PhD, Post-doctorate trainee, Department of Restorative Dentistry, Dental Materials, Piracicaba School of Dentistry, University of \\ Campinas, Piracicaba, SP, Brazil. \\ 5- DDS, PhD, Associate Professor, Department of Prosthodontics, Bauru School of Dentistry, Sao Paulo, Brazil. \\ 6- DDS, PhD, Professor and Head Division of Diagnostics, Infectious Disease and Health Promotion, New York University College of Dentistry, USA. \\ 7- DDS, PhD, Chairman of the Department of Biomaterials and Biomimetics, New York University College of Dentistry, USA.
}

Corresponding address: Dr. Nelson RFA Silva, Department of Prosthodontics - Arnold and Marie Schwartz Hall of Dental Sciences 345 East $24^{\text {th }}$ Street (Rm 813) - New York, NY 10010 - Phone: 212-998-9365, Fax: 212-995-4244

Received: November 03, 2005 - Modification: February 02, 2006 - Accepted: September 04, 2006

\begin{abstract}
I ntroduction: Disinfection of dentin surfaces is desirable so long as it does not interfere with subsequent bonding of adhesive resins. Objective: To test the null hypothesis that bond strengths to dentin are not affected by previous application of an iodine disinfecting solution. Materials and Methods: Twenty-four extracted non-carious molars were selected. Occlusal enamel was removed producing a flat dentin substrate. Test teeth were all treated with $2 \%$ Iodine disclosing/disinfecting solution (I DDS) for 20 sec and rinsed for 20 sec followed by the application of self- or total- etching bonding systems, generating five adhesive groups ( $\mathrm{n}=3$ ): Single Bond; ; Prime \& Bond NT; Clearfil SE Bond; Opti-Bond Plus. The control groups ( $\mathrm{n}=3$ per adhesive) had no disclosing/disinfectant application prior to adhesive application. A 4-mm thick resin restoration was built up on each tooth for microtensile testing. Statistical analyses between experimental and control groups were performed by student's t-test $(\alpha=0.05)$. Results: In general, experimental groups (previously treated with $\left.\mathrm{I}_{2} \mathrm{DDS}\right)$ showed significantly lower bond strength values when compared with their respective controls $(p<0.05)$, except for group Prime \&Bond $I_{2}$ that did not significantly differ from its control ( $>>0.05$ ). Conclusion: Acetone-base adhesive systems seem not to be affected by the application of $\mathrm{I}_{2} \mathrm{DDS}$ prior to etching and bonding procedures.

Uniterms: Dentin; Dentin-bonding agents; Iodine; Dentin sensitivity.
\end{abstract}

\section{RESUMO}

$I$ ntrodução : A desinfecção das superfícies de dentina é desejada desde que não haja interferência na adesão dos agentes adesivos. Objetivo: Testar a hipótese nula de que a resistência adesiva não é afetada pela aplicação prévia de uma solução desinfetante de iodo. Material and Método: Vinte e quatro molares hígidos foram selecionados. O esmalte oclusal destes dentes foi removido, e sobre as superfícies planas de dentina expostas foi aplicada da solução desinfetante de Iodo a 2\% (I DDS), que permaneceu sobre a superfície por 20 s e foi lavada por 20 s com água deionizada. Sobre as superfícies desinfetadas foram aplicados um dos seguintes sistemas adesivos (n=3): Single Bond; Prime \& Bond NT; Clearfil SE Bond; Opti-Bond Plus. Os grupos controle $(n=3)$ não tiveram a supeficie de dentina tratada com I DDS antes dos precedimentos adesivos. Em todos os grupos, após hibridização da dentina, foi construída uma "restauração" de resina composta com cerca de $4 \mathrm{~mm}$ de espessura. Após 7 dias de armazenagem em água destilada, os dentes foram secionados de modo a originarem espécimes a serem submetidos ao teste de microtração (palitos). Análise estatística para comparação dos dados foi realizada pelo teste t de student $(\alpha=0,05)$. Resultados: De forma geral, os grupos experimentais (tratados com I $_{2}$ DDS) apresentraram resistência adesiva significativamente menor do que os respectivos grupos controle $(\mathrm{p}<0.05)$, exceção se fez apenas para o grupo $\mathrm{P} \& \mathrm{BI}{ }_{2}$, que não diferiu significativamente de seu grupo controle P\&BC ( $>0.05)$. Assim, a hipótese nula deve ser rejeitada para os adesivos a base de etanol e/ou a base de água, mas aceita para 0 adesivo a base de acetona. Conclusão: $\mathrm{O}$ uso da solução experimental de iodo previamente à realização dos procedimentos adesivos afetou a efetividade da união à dentina apenas quando do emprego de sistemas adesivos a base de etanol e/ou água.

Unitermos: Dentina; Adesivos dentinários; Iodo; Sensibilidade dentinária. 


\section{INTRODUCTION}

Incomplete removal of bacterially contaminated dentin or enamel associated with caries is a potential problem in restorative dentistry. Bacteria can remain in the smear layer or in dentinal tubules, and can potentially multiply. Studies ${ }^{6,7}$ indicate that residual bacteria might proliferate from the smear layer beneath restorations, allowing toxins to diffuse to the pulp, resulting in irritation and inflammation ${ }^{3}$.

It is argued that microorganisms that are present in the cavity walls cannot be removed by the use of water spray or by the effect of restorative materials containing disinfecting agents $^{8}$. Therefore, the adjunctive use of antibacterial solutions after cavity preparation may be considered as an important tool on reducing the potential for both microorganism growth and hypersensitivity ${ }^{2}$.

A $2 \%$ Iodine disclosing/disinfecting solution ( $\mathrm{I}_{2} \mathrm{DDS}$ ) has been used to disclose and kill bacteria in plaque, hence working as "toilet" for caries removal ${ }^{4}$. Based on this bactericidal effect, $\mathrm{I}_{2} \mathrm{DDS}$ could be an appropriate agent to clean and disinfect dentin and enamel substrates prior to restorative procedures. However, a potential problem of using disinfectant solutions before bonding restorative procedures could be an interference with the ability of hydrophilic monomer resins to wet, diffuse and polymerize in situ into dentin substrates.

Due to the lack of information about $\mathrm{I}_{2}$ DDS application as a disinfectant agent applied prior to adhesive restorations, this study tested the null hypothesis that the adhesive bond strengths obtained via microtensile method ${ }^{11}$ are not affected whenever $I_{2}$ DDS is used prior to application of a range of bonding systems.

\section{METHOD AND MATERIALS}

The materials used in this study are listed in Table 1. Twenty-four freshly extracted non-carious molars were selected. All teeth were gamma-irradiated to ensure sterility and then stored in water ${ }^{14}$. The occlusal enamel was removed perpendicular to the long axis of the tooth using a slowspeed saw (Buehler Isomet Low Speed Saw with Buehler Diamond Wafering Blade - Series 20 HC Diamond, No 114215, Buehler, USA) to expose a flat dentin surface that was

TABLE 1- Table of Materials. This table shows the materials used in this study

\begin{tabular}{|c|c|c|c|}
\hline Material & Composition & Lot & Company \\
\hline $\begin{array}{l}\text { Single Bond } \\
\text { (self-priming) }\end{array}$ & $\begin{array}{l}\text { Bis-GMA; Polyalkenoic acid co-polymer; Dimethacrylates; } \\
\text { HEMA; Photoinitiator; Ethanol; Water }\end{array}$ & 1FM & 3M- St. Paul MN 55144 \\
\hline $\begin{array}{l}\text { Prime \& Bond NT } \\
\text { (self-priming) }\end{array}$ & $\begin{array}{l}\text { Di-and Trimethacrylate resins, PENTA, Cetylamine } \\
\text { hydrofluoride, Acetone, Nanofillers, Stabilizers }\end{array}$ & 020227 & Dentsply-Milford, DE 19963 \\
\hline $\begin{array}{l}\text { Clearfil SE Bond } \\
\text { (self -etching) }\end{array}$ & $\begin{array}{l}\text { 10-Methacryloyloxydecyl dihydrogen phosphate (MDP); } \\
\text { Bis-phenol A diglycidylmethacrylate (HEMA); Hydrophobic } \\
\text { dimethacrylate; dl-Camphorquinone; N, } \\
\text { N-Diethanol-p-toluidine; Silanated colloidal silica; water }\end{array}$ & $\begin{array}{l}61243 \\
327\end{array}$ & $\begin{array}{l}\text { Kuraray- } 200 \text { Park Ave. } \\
\text { New York, NY } 10166\end{array}$ \\
\hline $\begin{array}{l}\text { Opti Bond Solo } \\
\text { Plus } \\
\text { (self-priming) }\end{array}$ & Acrylates, ethanol & 012785 & $\begin{array}{l}\text { Kerr USA-1717 West Collins } \\
\text { Ave Orange, Ca } 92867\end{array}$ \\
\hline Etchant & 35\% Phosphoric Acid & $1 \mathrm{ET}$ & 3M- St. Paul MN 55144 \\
\hline Z 100 & BIS-GMA, TEGDMA resins & $2 \mathrm{CJ}$ & 3M- St. Paul MN 55144 \\
\hline $\begin{array}{l}2 \% \text { lodine } \\
\text { Disclosing/ } \\
\text { Disinfection } \\
\text { Solution } \\
\left(\mathrm{I}_{2} \mathrm{DDS}\right)\end{array}$ & $\begin{array}{l}\text { In volumetric } 100 \mathrm{ml} \text { flask - } 2 \mathrm{gm} \mathrm{I}_{2} \text { (USP); } 2.4 \mathrm{gm} \mathrm{KI}(\mathrm{USP}) \text {; } \\
53 \mathrm{ml} \text { Glycerol (USP); } \mathrm{H}_{2} \mathrm{O}\end{array}$ & - & $\begin{array}{l}\text { New York University, } \\
345 \text { East 24th street, } \\
\text { NY, } 10010\end{array}$ \\
\hline
\end{tabular}


subsequently finished using 600-grit silicon paper (Buehler, Phoenix Beta Polisher and grinder).

In all experimental groups, the dentin surfaces were treated using an I DDS (Table 1) for 20 seconds and then rinsed for 20 seconds followed by the application of self- or total etching adhesive systems, therefore generating five bonding groups (3 teeth per group) as listed below:

$\mathrm{SBI}_{2}$ : Single Bond (3M-ESPE Co, USA)

$\mathrm{P} \& \mathrm{BI}_{2}$ : Prime \& Bond NT (Dentsply, USA)

$\mathrm{SEI}_{2}$ : Clearfil SE Bond (Kuraray Co, Japan)

$\mathrm{OPTBI}_{2}$ : Opti-Bond (Kerr Co, USA)

In the control groups (3 teeth per group), the disinfectant solution was not applied and the groups were defined as SBC, P\&BC, SEC, and OPTBC for respective adhesive systems.

The adhesive agents were applied and photo-activated (Curing Light 2500, 3M-3350 Granada Ave. N Oakdale, MN 55128, USA) according to the manufacturers' directions.

Following adhesive application, a 4-mm resin restoration was built up on the bonded surface using Z 100 composite (3M- ESPE , St. Paul, MN 55144, USA) in increments of not more than $1.5 \mathrm{~mm}$. Each increment was light cured for 40 seconds. All teeth were then aged for a period of 7 days in water at $37^{\circ} \mathrm{C}$.

After aging, the specimens were cross-sectioned perpendicular to the adhesive interface with a slow-speed saw (Buehler Isomet low speed saw with Buehler Diamond Wafering Blade - Series 20 HC Diamond, No 11-4215, Lake Bluff, IL, USA) under copious water, to produce a series of squared beams of approximately $0.8-\mathrm{mm}$ per side and 8-mm length. Each beam was attached to the flat grips of a special jig (Bencor Multi-T, Bencor, Calgary, Alberta, Australia) using cyanoacrylate cement (Krazy Glue Gel, Advanced FormulaELMER'S Products, Inc, USA) and loaded to failure under tension at a crosshead speed of $12.7 \mathrm{~mm} / \mathrm{min}$ using a testing machine (Model TSD 500, Chatillon-Ametek, Agawam, MA 01001, USA). The cross-sectional areas of all specimens were measured individually, after bond testing, using a digital caliper (Mitutoyo, 20-1 Sakado, Kawasaki, Kanagawa 213, Japan), and this value was used to calculate the bond strength. The mean tensile bond strength (MTBS) data were converted to $\mathrm{MPa}$, and comparison between experimental and control groups of the different bonding systems were performed by student-t tests. Statistical significance was preset at $\alpha=0.05$. The mode of failure of each specimen was determined using Stereomicroscope (SXZ-ILLB 100,
Olympus Optical, Co, LTD, Japan) and classified as cohesive in resin composite, adhesive cohesive in dentin and mixed. ${ }^{11}$ Pre-testing failures due to handling and cutting procedures prior testing were not considered as a zero value for statistical analysis.

A separated group of dentin substrates were prepared following the same protocol of application of $\mathrm{I}_{2}$ DDS with and without etching step and then observed in the SEM (JEOL - JMS 5400 Scanning Microscope, Tokyo, Japan) to evaluate whether there was a change on the dentin substrate after the application of $\mathrm{I}_{2}$ DDS.

A drop of either an ethanol and/or water-based or acetone-based adhesive formulation was added to a drop of glycerol and observed under a stereomicroscope (SXZILLB 100, Olympus Optical, Co, LTD, Japan) to ascertain whether there could be a phase separation between the two agents.

\section{RESULTS}

Means and standard deviations of the bond strength for all groups are shown in Table 2. In general, experimental groups (previously treated with $\mathrm{I}_{2} \mathrm{DDS}$ ) showed significantly lower bond strength values when compared with their respective controls $(\mathrm{p}<0.05)$. An exception was the $\mathrm{P} \& \mathrm{BI}_{2}$, which did not significantly differ from its control P\&BC ( $>>0.05)$.

Mixed failure was found in approximately $75 \%$ of bond test specimens for both control and Iodine groups, respectively. Adhesive failure in dentin was observed in $16.6 \%$ of controls and $23.4 \%$ of Iodine treated specimens summed across all tested groups. This slight increase of adhesive failure mode for the iodine groups might be related to the possible presence of remnants of glycerol after application and rinsing of $\mathrm{I}_{2} \mathrm{DDS}$. Residual glycerol may be responsible for the decrease $(\mathrm{P}>0.05)$ of MTBS of water and/or ethanol based bonding agents. Cohesive mode of failure either in dentin of resin was observed in $8.3 \%$ of tested specimens in control groups and $4.3 \%$ of all tested specimen of Iodine groups.

Figure1 shows the effects of adding either an ethanol and/or water-based or acetone-based adhesive formulation to a drop of glycerol. The ethanol and/or water-based adhesive depict a phase separation, while the acetone adhesive is miscible with glycerol.

TABLE 2 - Table of results. This table shows the mean (M), standard deviation (SD) and number of tested specimens (N) for each adhesive system $(M \pm S D(N))$. The significance was determined at $P<0.05$

\section{Groups Single bond}

$(3 \mathrm{M})$

\section{Prime \& Bond}

(Dentsply)

\section{Clearfil SE Bond}

(Kuraray)

\section{Opti Bond Plus}

(Kerr)

\begin{tabular}{lllll}
\hline I.DDS & $34.9 \pm 14.0^{\mathrm{b}}(\mathrm{n}=77)$ & $37.8 \pm 14.4^{\mathrm{b}}(\mathrm{n}=46)$ & $24.8 \pm 13.3^{\mathrm{b}}(\mathrm{n}=59)$ & $23.2 \pm 12.7^{\mathrm{b}}(\mathrm{n}=54)$ \\
Control & $44.2 \pm 15.9^{\mathrm{a}}(\mathrm{n}=61)$ & $37.1 \pm 14.8^{\mathrm{b}}(\mathrm{n}=39)$ & $36.3 \pm 12.9^{\mathrm{a}}(\mathrm{n}=59)$ & $39.5 \pm 14.7^{\mathrm{a}}(\mathrm{n}=49)$ \\
\hline
\end{tabular}

a, b: statistically significance between experimental and control groups. 
When $\mathrm{I}_{2}$ DDS was applied to dentin surface before etching, fewer opened-tubules were observed in the dentin, compared to the etched only dentin surface (Figure 2). This suggests that residual glycerol or iodine affects on the smear layer or collagen reduces the acid dissolution of the dentin surface.

\section{DISCUSSION}

During clinical procedures, prepared dentin surfaces may be contaminated with saliva, blood, and microorganisms ${ }^{8}$. Saliva and blood contamination has been shown to reduce resin to dentin bond strengths, depending greatly upon adherent surface condition ${ }^{5}$. However, no bacteria were found when the cavity was cleaned with a microbiocidal fluoride solution and leakage was eliminated ${ }^{1}$. These observations suggest that prepared surfaces need to be cleaned to eliminate bacteria ${ }^{2}$ before lining, cementation, and restoration.

Using disclosing and/or disinfectant solutions on dentin before application of adhesive systems could potentially interfere with the ability of adhesive to micromechanically bond to the dentin, and consequently reduce bond strength. In 2002, Wahl, et al. ${ }^{13}$ tested the effect of different disinfectant rinses (distilled water as a control; water with 3.5 ppm iodine; water $3.0 \mathrm{ppm}$ sodium hypochlorite; water with $2 \%$ ethanol; water contaminated with $6 \times 10^{4} \mathrm{cfu} / \mathrm{ml}$ of E. coli $\mathrm{BH} 5 \alpha$ ) applied following acid etching of dentin. This was followed by application of Single Bond adhesive and resin-based composite. They observed that the disinfectant water rinse had no significant effect on the shear bond strength of resindentin bonds. They also concluded that further work was needed to evaluate the effect of antimicrobial agents on adhesive bond strength of various adhesive systems (alcohol/water based and/or acetone based). Wahl's group ${ }^{13}$ employed shear testing while in our work the microtensile bond method ${ }^{11}$ was utilized.

Application of an $\mathrm{I}_{2}$ DDS prior to adhesive application resulted in reduced microtensile bond strength values for ethanol- and/or water-based adhesive systems and not for the one acetone-based adhesive system tested. Ethanol-

\section{Acetone Base Adhesive}

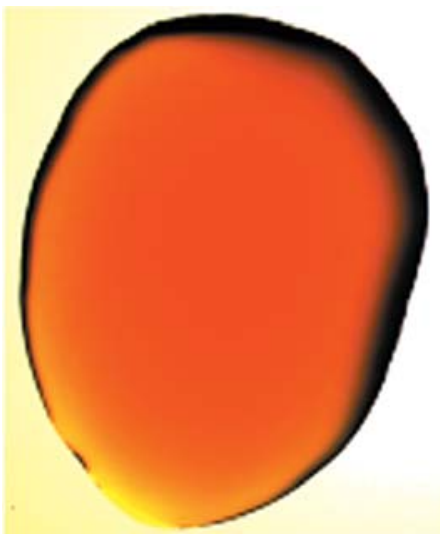

2\% lodine Before Addition

\section{Water/Ethanol Base Adhesive}

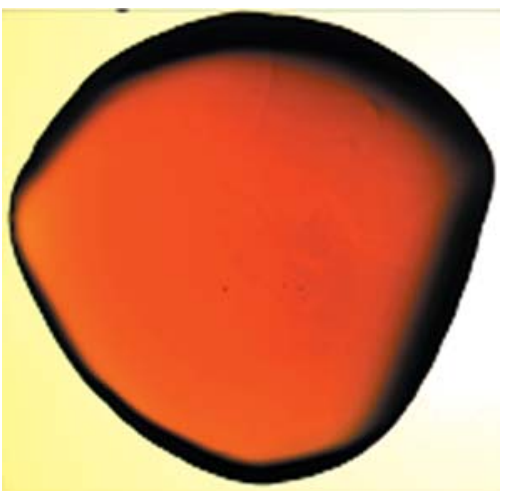

2\% lodine Before Addition

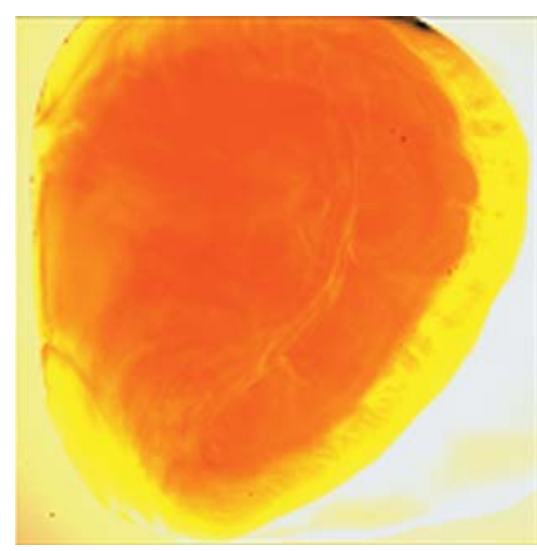

3 s After Addition

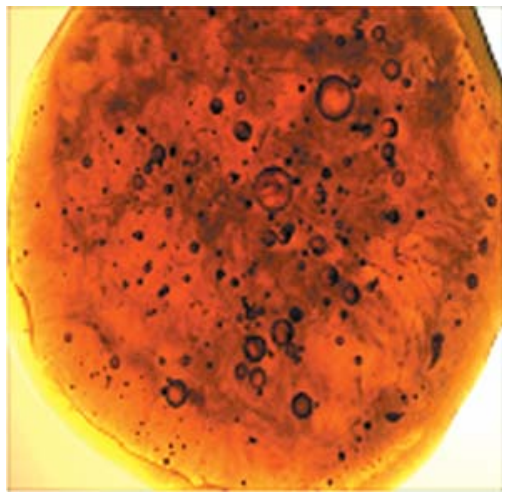

3 s After Addition

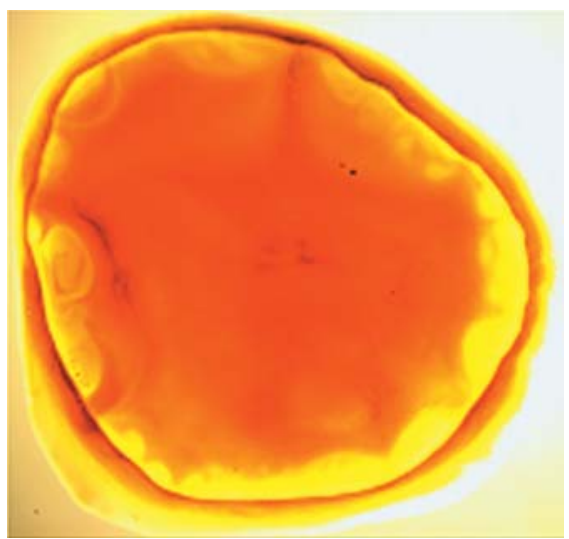

3 min After Addition

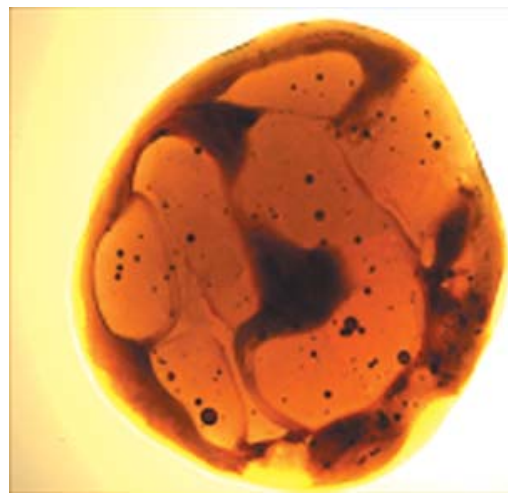

3 min After Addition

FIGURE 1- This sequence shows the stereomicroscopic images from one drop of the $\mathrm{I}_{2}$ DDS mixed with one drop of acetonebased adhesive and water- and/or ethanol-based adhesive ( 3 seconds and 3 minutes after addition). Observe that the adhesive with water content cannot diffuse through the disinfecting solution, presenting phase separation probably between the water and the glycerol 
and/or water-based adhesive systems (Single Bond; Clearfil SE Bond; and Opti-Bond Plus) had statistically lower bond strengths $(\mathrm{p}<0.05)$, suggesting that $\mathrm{I}_{2} \mathrm{DDS}$ interferes with the adhesive bond strength.

$I_{2}$ DDS is a dark solution. However, the application of $\mathrm{I}_{2} \mathrm{DDS}$ followed by a rinse step and bonding procedures did not have immediate influence on esthetic outcomes of restorations.

Reduction in bond strength values for ethanol- and/or water-based adhesive agents might be due to the presence of glycerol (53\%) in the composition of $\mathrm{I}_{2} \mathrm{DDS}$. Glycerol is used as a "carrier" for I DDS. We speculate that remnants of the glycerol "carrier" might be incompletely removed from the dentin substrate after water rinsing (20s), drying and even etching procedures. Glycerol is highly viscous, and is soluble in water only when extensive mechanical mixing occurs. When ethanol and/or water-based adhesive agents were used, residual glycerol might prevent adhesive from diffusing through demineralized dentin surface interfering with hybrid layer formation. Phase separation between the water/ethanol adhesive and glycerol might occur during evaporation of these solvents (Figure 1). Deficiency of monomer penetration into demineralized layer could decrease the bond strength. However, for acetone-based adhesive system used in this study, acetone seemed to be able to diffuse into residual glycerol and allow monomer penetration into demineralized dentin, and thus does not produce a significant difference in bond strength value. This indirectly indicates a plausible basis for bond strength differences, should residual glycerol remain on the surface.

The application of I DDS might also lead to variation in the surface demineralization by phosphoric acid etching, suggesting the presence of I DDS remnants on the dentin substrate even after etching procedures. These remnants may limit the etchant to reach the collagen network and thereby work as a barrier for adhesive interlock into dentin, potentially leading to both microleakage and lower bond strengths ${ }^{12}$.

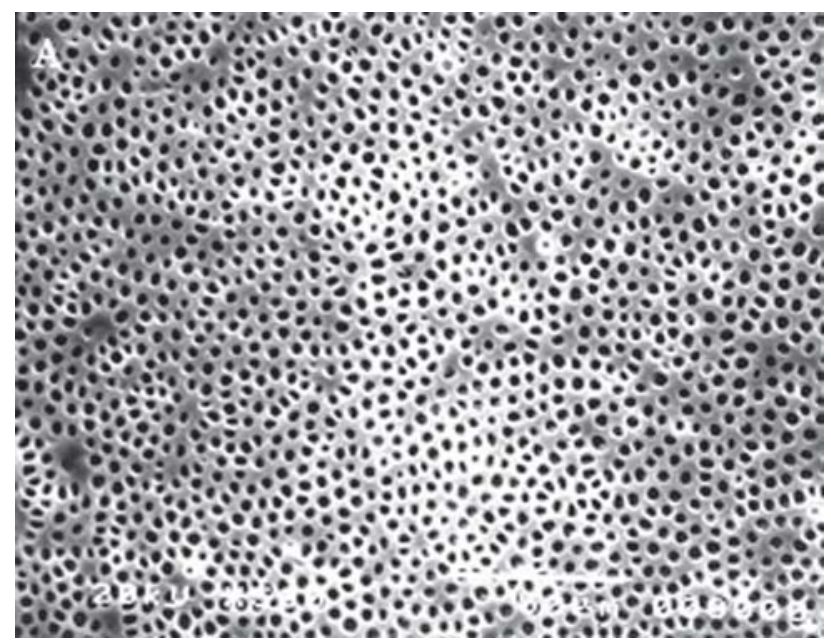

In 2000, Roberts, et al. ${ }^{10}$ tested dentin bond strength using four chemical agents developed for the reduction of bacterial contamination in dental treatment water. The authors also observed reduction in dentin bond strength and speculated that this might be caused by essential oils present in these products, which might jeopardize tag formation.

The application of disclosing and/or disinfecting agents is an important step in clinical procedures. It can prevent bacterial growth and consequently diminish the possibility of post-operative hypersensitivity after restorative treatment. To be more conclusive about utilization of I DDS as a disinfectant before adhesive procedures, further studies are warranted to elucidate how bond strength of water- and/ or ethanol-based adhesive systems might increase such as rinsing specimen longer than 20 seconds with water to remove any solution residue. Investigations into the role of glycerol on lower bond strengths should be pursued by using Iodine solutions based upon water alone associated with transmission electron microscopic evaluation (TEM).

\section{CONCLUSION}

Acetone-based adhesive systems seem not to be affected by the application of $\mathrm{I}_{2}$ DDS prior etching and bonding procedures. The null hypothesis can be rejected for ethanoland/or water-base adhesives ( $\mathrm{p}<0.05)$ : Single Bond, Clearfil SE bond, and Opti-Bond Plus, in which $\mathrm{I}_{2}$ DDS application reduces bond strength.

\section{ACKNOWLEDGEMENTS}

The authors are grateful to the Department of Biomaterials, Department of Prosthodontics and Department of Cariology and Operative Dentistry of New York University-College of Dentistry - USA, and Department of

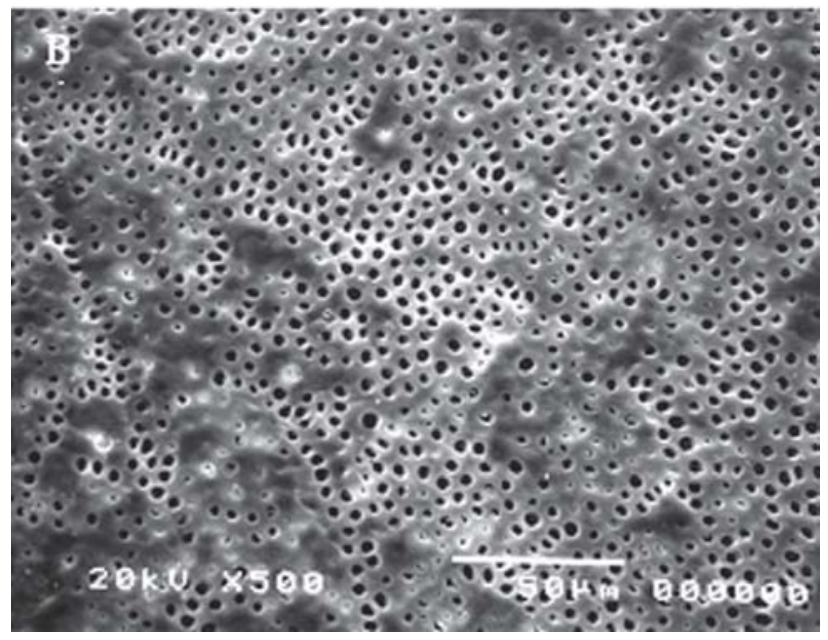

FIGURE 2- These 500x Scanning Electron Micrographs present: A) Dentin surface after etching procedure with $35 \%$ phosphoric acid; B) Dentin surface after $2 \%$ iodine disinfecting/disclosing treatment and etching procedure with $35 \%$ phosphoric acid. Note the fewer number of opened tubules on the surface treated by $\mathrm{I}_{2}$ DDS previous the etching and bonding procedures, suggesting the presence of remnants after rinsing the substrate with water for 20 seconds 
Prosthodontics of Bauru School of Dentistry (FOB-USP) and CNPq Grants 201471/2003-5, 305300/2004-0 and 474226/ 03-4.

\section{REFERENCES}

1- Brannstrom M, Nyborg H. Cavity treatment with a microbicidal fluoride solution: growth of bacteria and effect on the pulp. J Prosthet Dent. 1973;30(3):303-10.

2- Brannstrom M, Johnson G. Effects of various conditioners and cleansing agents on prepared dentin surfaces: a SEM investigation. J Prosthet Dent. 1974;31(4):422-30.

3- Brannstrom M. The cause of post-restorative sensitivity and its prevention. J Endod. 1986;12(10):475-81.

4- Caufield PW, Gibbons RJ. Suppression of Streptococcus mutans in the mouths of humans by a dental prophylaxis and topically-applied iodine. J Dent Res. 1979;(58):1317-26.

5- Johnson ME, Burgess JO, Hermesch CB, Buikema DJ. Saliva contamination of dentin bonding agents. Oper Dent. 1994;19(6):20510 .

6- Meiers JC, Kresin JC. Cavity disinfectants and dentin bonding. Oper Dent. 1996;12(4):153-9.

7- Meiers JC, Shook LW. Effect of disinfectants on the bond strength of composite to dentin. Am J Dent. 1996;9(1):11-4.

8- Molgatini S, Abate PF, Negroni MB, Macchi RL, Gonzalez MI. Bacterial inhibition produced by substances for dentin pretreatment. Acta Odontol Latinoam. 1993;7(2):3-9.

9- Pashley DH, Carvalho RM, Sano H, Nakajima M, Yoshiyama M, Shono Y, Fernandes CA, Tay F. The microtensile bond test: a review. J Adhes Dent. 1999;1(4):299-309.

10-Roberts HW, Karpay RI, Mills SE. Dental unite waterline antimicrobial agents' effect on dentin bond strength. J Am Med Assoc. 2000;131(2):179-83.

11- Sano H, Sonada H, Shono T, Takatsu T, Ciucchi B, Carvalho R. Relationship between surface area for adhesion and tensile bond strength-evaluation of micro tensile bond test. Dent Mater. 1994;10(4):236-40

12- Turkun M, Turkun S, Kalender. Effect of cavity disinfectants on the sealing ability of nonrinsing dentin-bonding resins. Quintessence Int. 2004;35:469-76.

13- Wahl AJ, Combe EC, Polack MA, Martens, LV. Effect of water quality on the bonding of resin to moist dentin. Am J Dent. 2002;15(2):114-6.

14- White JM, Goodis HE, Marshall SJ, Marshall GW. Sterilization of teeth by gamma radiation. J Dent Res. 1994;73(9):1560-67.

15- Yoshiyama M, Urayama A, Kimochi T, Matsuo T, Pashley DH. Comparison of conventional vs self-etching adhesive bonds to cariesaffected dentin. Oper Dent. 2000;25(3):163-9. 